\title{
Performatividad, dispositivos y política. Fuerzas especiales de Diamela Eltit ${ }^{*}$
}

\section{Luis Valenzuela Prado**}

\section{Resumen}

Este artículo propone una lectura de la novela Fuerzas especiales de Diamela Eltit, la cual configura una retórica visual o de una letra en tránsito hacia la imagen desde una interpretación ranceriana de lo político. Sobre esta base, se busca desarrollar dos objetivos: el primero, articular una lectura en torno a las nociones de política, en cuanto todo cruce entre letra, medios, imágenes y dispositivos implica un choque y una fricción, que siempre cargan con otras tensiones políticas y culturales; el segundo, analizar las variantes que posibilitan hablar de una retórica del espectáculo, la escena y la imagen.

Palabras clave: Política, espectáculo, dispositivos, Diamela Eltit.

\section{Performativity, devices, and politics. Fuerzas especiales by Diamela Eltit}

\begin{abstract}
This article proposes a reading of the novel Fuerzas especiales, by Diamela Eltit, which configures a visual rethoric or from the written letter in transit towards image, from a Rancierian reading of the political. On this basis, two objectives are sought: first, articulating a reading around the notions of politics, considering that every crossover between writing, media, images and devices implies clash and friction, which always bring other cultural and political tensions; the second, analyzing the variants that enable talking about a performance, scene and image rethoric.
\end{abstract}

Keywords: Politics, Espectacle, Devices, Diamela Eltit.

Este artículo forma parte del proyecto FONDECYT de Iniciación "Retóricas del espectáculo. Articulaciones entre la novela y el cine en Chile y Argentina. 2001-2015”, del cual soy el investigador responsable.

Chileno. Doctor en Literatura. Universidad Andrés Bello. Santiago, Chile. luis.valenzuela.p@unab.cl 
“... las tensiones entre las representaciones visuales y las verbales no pueden desligarse de las luchas que tienen lugar en la política cultural y la cultura política".

W. J. T. Mitchell. Teoría de la imagen

“Todas las luchas derivadas del poder y el deseo han de tener lugar aquí, entre el dominio de la mirada y la riqueza ilimitable del objeto visual".

Fredric Jameson. Signaturas de los visible

\section{De la literatura menor a la política de la literatura}

Hablemos de letras y de imágenes, de los tránsitos entre unas y otras. De política. De obras. El proyecto literario de Diamela Eltit es político y crítico, sin duda, y desde ahí ha sido leído y seguirá siéndolo. La letra política renueva su condición a partir de su intento de mostrarse, una letra que -desde Lumpérica hasta Fuerzas especiales- puede ser vista a la vez que interviene. Es una letra que busca y ambiciona erigir una imagen, una escena observada, y que, por tanto, articula una propuesta política. Desde el cruce letra-imagen, leo un esbozo de política intermedial, en el que lo intermedial es entendido como "síntoma de una búsqueda necesaria en el campo de las humanidades" y la producción artística, y cuya práctica intermedial apunta a "visibilizar programáticamente sus propios medios y la relación con otros medios y formas expresivas" (Bongers 152).

En ese sentido, la letra, desde su intrínseca condición, se problematiza al buscar ser imagen. Un momento que Derrida (2013) señala como aquel en que "el lenguaje se abre a las artes no verbales" (33). Este artículo analiza la novela Fuerzas especiales (2019) de Diamela Eltit desde su estética visual proponiendo una lectura ranceriana de lo político. De este modo, se buscan dos objetivos específicos: el primero, articular una lectura en torno a la noción de política, en tanto que todo cruce entre letra, medios, imágenes y dispositivos implica un choque y una fricción social y cultural; el segundo, en consonancia con el anterior, analizar las variantes que posibilitan hablar de una retórica del espectáculo, la escena y la imagen, a partir de la lectura de diversos gestos y materiales puestos en escena: cuerpo y mercancía, espacios y materiales, dispositivos de la imagen, relato y juego.

En clave ranceriana, hablo de la política de la literatura desde una arista que se desentiende de "la política de los escritores" (El reparto 
de lo sensible. Estética y política 15), que no apunta a los "compromisos personales en las pujas políticas o sociales", así como del modo en que "estos [escritores] representan en sus libros las estructuras sociales, los movimientos políticos o las diversas identidades". Continúa Rancière:

la expresión 'política de la literatura' implica que la literatura hace política en tanto literatura [...] La expresión 'política de la literatura' implica, entonces, que la literatura interviene en tanto que literatura en ese recorte de los espacios y los tiempos, de lo visible y lo invisible, de la palabra y el ruido. Interviene en la relación entre prácticas, entre formas de visibilidad y modos de decir que recortan uno o varios mundos comunes. (16-7)

La intervención -como gesto intrínseco de la literatura- se relaciona con otros conceptos que el mismo filósofo aborda en sus textos. Recuerda Rancière que "la política es cuestionada a partir de lo que se conoce como 'reparto de lo sensible'" (El reparto de lo sensible estética y política 20). Cuestionamiento que es coherente con las ideas de desclasificación, la idea de oposición entre espectador de teatro activo y pasivo, la del gesto de hacerse parte del reparto, la de las imágenes que se desatan de los significados con los que estas cargan. En todos esos conceptos -se puede discutir- Rancière erige un gesto que deriva en la idea del desmarque, del cuestionar el estatus, en el caso de Eltit, político de la letra. Un complemento al concepto surge desde la línea trazada por Deleuze y Guattari (1978) al pensar la "literatura menor", una literatura de la subversión, aquella en la que "su espacio reducido hace que cada problema individual se conecte inmediato con la política" (29). ${ }^{1}$ Esta confluencia permite articular un concepto en el que todo espacio individual llega a lo político y esta convergencia es leída desde la dislocación de los lugares del reparto. Un gesto de dislocación de la letra y la novela, el poder y la autoridad, el espacio y el territorio.

Los epígrafes que abren este artículo configuran una operación cuyas tensiones entre representaciones visuales y verbales, sostiene Mitchell, no se apartan de las disputas "en la política cultural y la cultura política", por su parte, afirma Jameson, toda lucha derivada del poder encuentra un lugar "entre el dominio de la mirada y la riqueza ilimitable del objeto

Una lectura que profundiza la lectura de la "literatura de lo menor" en Eltit es el trabajo de Juan Carlos Lértora (1993), una literatura "producida en el espacio de un lenguaje mayor pero que desde dentro se propone cuestionar y subvertir sus mecanismos" (28). 
visual" (31). Entonces, letra e imagen conjugan una lectura política que interviene, subvierte, ejerce un modo de tirantez. En ese sentido, siguiendo a Evans y Hall (2016), una cultura intervenida por diversas tecnologías "diseñadas para propagar prácticas de mirar y ver" a través de formas visuales "plantea un desafío", en tanto rastreo de maneras en que la imagen está articulada "con sensibilidades productoras de imágenes en una 'cultura visual' más amplia" (102). Lo relevante, entonces, radica en la articulación de tales representaciones, un cruce complejo y crítico.

En sí, la literatura, como política, debe intervenir espacios y campos. ¿Por qué intervenir? George Didi Huberman (2012) afirma que, tanto las imágenes como los pueblos, "han sido previamente reducidos" y explica: "las primeras a puros procesos de sometimiento y los segundos a puros cuerpos sometidos" (78), por lo que el gesto político radicaría en, al menos, cuestionar dicho estado. La imagen no está sola, involucra otros elementos y sujetos, por ejemplo, el espectador, cuya relación con la imagen redunda en la bi-direccionalidad de la mirada, hacia y desde un cuerpo: “Mi cuerpo como cosa visible está contenido en el gran espectáculo. Pero mi cuerpo vidente subentiende este cuerpo visible y con él todos los seres visibles. Hay una inserción recíproca y entrelazamiento entre uno y otro" (Merleau-Ponty 171). Toda forma de visualización es compleja, de hecho, Rancière (2010), en una línea que articula tanto a Merleau-Ponty como a Evans y Hall, afirma que una “imagen jamás va sola", siempre está articulada con un "dispositivo de visibilidad que regula el estatuto de los cuerpos representados y el tipo de atención que merecen" (99).

Eltit, en su proyecto, busca delinear un ejercicio en el que hace eco la configuración de imagen antes comentada. En rigor, proyecta una visualidad compleja, crítica y activa en la letra. Eltit desentraña un relato que acumula imágenes y escenas, o en palabras de Guy Debord (2012), espectáculos: "La vida entera de las sociedades en las que imperan las condiciones de producción modernas se anuncia como una inmensa acumulación de espectáculos" (37), como escenas, como imágenes. El espectáculo "como la sociedad misma, como una parte de la sociedad y como instrumento de unificación" (38), como "una relación social entre personas mediatizada por imágenes" (38), como "el corazón del irrealismo de la sociedad real" (39). El espectáculo que somete a los hombres, pues la economía los ha configurado como "una fabricación concreta de la alienación" (39). Espectáculo que ya en los años treinta 
es vinculado a los estados autoritarios (Benjamin, 2008) y que en el siglo XXI es articulado desde la intimidad y la escritura del yo (Sibila, 2013). Espectáculo que entra en tención con el recorte de los espacios rancerianos.

\section{Escenas, performances y espectáculos}

Desde Lumpérica -una novela poética y experimental-, Diamela Eltit remece el tranquilo lugar de la letra narrada. Fundada desde la "pluralidad de registros y códigos de lenguaje" (Olea 177) y cargada de visualidad, se proyecta en el resto del trabajo escritural de esta autora: espectáculo, escena, imagen, visualidad (Rojas, 2013).

La narrativa de Eltit, publicada en los ochenta y noventa, clama por una imagen. Mano de obra (2002) propone un ojo vigilante que espectaculariza la rutina laboral de los cuerpos de los trabajadores -el funcionario del supermercado "se transforma en un observador de la condición humana" (Rojas 169)-, que devienen en mercancía en medio de los pasillos del supermercado, donde trabajadores y clientes entran en la dinámica del cuerpo-mercancía: "Me convertí también en un avezado catador de clientes" (Eltit 34). La rutina del trabajo se espectaculariza desde el exceso como "signo de una catástrofe, un acontecimiento inmemorial a partir del cual todo ha comenzado a funcionar en torno al despertar de la necesidad" (Rojas 170)2 . Se puede hablar, entonces, de una cadena: espectáculo-mercado-catástrofe, en una lógica neoliberal “de trabajadores paupérrimos del capitalismo" (Carreño 65) que detecta la crisis de la sociedad y del estado moderno anunciado en los años sesenta por Guy Debord. Tanto en Mano de obra como en Fuerzas especiales se problematiza la mirada, en tanto escena y en tanto dispositivo.

La cadena mercantil que somete a los personajes de la novela logra ser puesta en tela de juicio desde la escritura/letra y el lenguaje en dos dimensiones: por una parte, se articula una "memoria de artistas e

Sergio Rojas también atiende, en Por la patria, a la figura de los alacranes, "imágenes de lo irrepresentable [que] dan cuerpo visual a un acontecimiento devastador" (66); en Vaca sagrada al sueño de Francisca, "visual, escénico" (105) y a la "Otra imagen-visión" del exhibicionista que se muestra y que es visto; en Los trabajadores de la muerte recupera lo que en Eltit se narra hacia el final de la novela, "la confusa escena en las calles de Santiago" (163), incluidas las “Cámaras de vigilancia apostadas en las esquinas" (164), haciendo el gesto ecfrástico de la escena; en Jamás el fuego nunca al cruce de "imágenes hechas de palabras en esa habitación" (188); en El Cuarto Mundo al universo que "se vuelve un multitudinario escenario" (92). 
intelectuales" con los títulos de "periódicos obreros [que] aluden a un pasado organizado" (Carreño 65); por otra, se desestabilizan ciertas operaciones mercantiles con "la fuerza del lenguaje procaz", que "luchará contra la mercantilización/precarización de las relaciones comunitarias [...]" (Barros 237). El lenguaje, como en toda la obra de Eltit, se erige en un articulador político.

El espacio marginal del cibercafé pone énfasis en la exclusión de los personajes-cuerpos de la novela, que se manifiestan como proyección intrínseca de un proyecto escritural que asume una transversalidad de "personajes paupérrimos del capitalismo" (Carreño). En Los vigilantes y El cuarto mundo, por ejemplo, en lugar de elegir "oppressive societies, they prefer to be homeless, sexual deviants, or drug addicts. The characters embark in a journey that challenges normativity -by disobeying prescribed norms they challenge the mechanism of power" (Phillips 191). En el caso de Fuerzas Especiales "se inserta en el realismo social y la alegoría posépica, la microhistoria de una derrota y de los vencidos, aquellos seres que el sistema neoliberal intenta destruir sin conmiseración alguna" (Espinosa 227). Desde aquí también resulta pertinente pensar en otros ecos de la narrativa chilena como el tono onírico de María Luisa Bombal, en La última niebla (1934), el aspecto social del block en tanto espacio del conventillo como residuo de la nación, en Los Hombres obscuros (1939) de Nicomedes Guzmán -leído por Lucía Guerra (2000)- e, incluso, ciertos ecos de Eloy (2008) de Droguett.

En ese sentido, los ecos del conventillo de Guzmán se proyectan en las pensiones de los relatos de Manuel Rojas o en el rancho donde va a caer Eloy. Así, la figura del bloque ${ }^{3}$ exacerba tanto la marginalidad de la construcción urbana como de la ficcional, que remite a la novela como constructo y representación: "Observo los bloques y trato de imaginarme un mundo estrictamente rectangular e inamovible" (59). Desde ese lugar, en Fuerzas especiales emerge una visualidad, una escenificación y una espectacularización latentes, que están en coherencia con el proyecto político y crítico de Diamela Eltit. La novela se articula en tres ejes centrales: el primero, el cuerpo prostituido frente a la pantalla del cibercafé y la performatividad imaginada de la autoridad, en una

El bloque, el que la protagonista habita, es la "representación del bloque miedo, una forma gráfica que podría levantarse, hincharse, inflarse cualquier día y explotar como un tubo de gas porque la presión del miedo llegaría a niveles inmanejables y el estallido sería la única forma de consumación" (89). 
estrategia de desespectacularización de los cuerpos; el segundo, la articulación de diversas materialidades de la imagen y los dispositivos que las canalizan; y el tercero, la configuración de una narrativa audiovisual desde el videojuego. En síntesis, constituyen formas que exacerban la visualidad y que encadenan un diálogo con ciertas tecnologías, dispositivos, construcciones o relatos, como crítica a las instituciones que las articulan.

\subsection{Desespectacularización: cuerpos en escena}

En el cíber y la pantalla -en tanto espacio público-cerrado-, el cuerpo ${ }^{4}$ se constituye en mercancía. Elina Matoso sostiene que el cuerpo -carne, fluido, hueso, finitud y contundencia- y su imagen -representación ineludible para que la carne esté viva en lo humano- no son "instancias duales sino como textura de la trama" (11), entendida "como construcción social. Devenir de la cultura. Carnalidad historiada" (11). En rigor, el cuerpo es el "anclaje de atravesamientos, filosóficos, históricos, económicos políticos, artísticos, psicológicos, culturales" (Matoso 11). En este sentido, el cuerpo como mercancía encuentra eco en la propuesta de Debord, que afirma que el "espectáculo es el momento en que la mercancía ha logrado la colonización total de la vida social” (54).

La mercancía como espectáculo, el cuerpo como mercancía ante la pantalla: "Voy al cíber como mujer a buscar entre las pantallas mi comida. Todos se comen. Me comen a mí también, me bajan los calzones frente a las pantallas" (Eltit 11). Una suerte de antropofagia en la lógica del cuerpo mercantilizado y explotado, donde el cíber degenera tal como lo hace el supermercado en Mano de obra ${ }^{5}$. Mientras es penetrada, en una suerte de antiespectáculo o de escena desespectacularizada, comenta con frialdad: "Nunca digo: sácame el lulo ni digo: sácame los dedos" (12). Tranquila observa la pantalla: un sitio de modas alternativas o una enorme mariposa (99), en una supuesta evasión superficial, donde el

Espinosa pone énfasis en el cuerpo: "Es importante destacar la radical importancia del cuerpo en esta escritura. Estamos ante cuerpos que operan como territorios de la derrota, territorios que se van destruyendo por los efectos de un acoso constante. Al sujeto material y simbólicamente despojado de toda dignidad, solo le queda el cuerpo como espacio de resistencia; sin embargo, el poder funciona como una permanente máquina deseante" (228).

Para Mónica Barrientos, el supermercado "se transforma en signo y símbolo de la degeneración de los sujetos y la penetración del poder en los cuerpos". Tal degeneración es revocada, en parte, ya que, para Loreto Montero, la narradora, en Fuerzas especiales, es un "sujeto que transita de vuelta de la degradación, en tanto su ejercicio de resistencia va más allá de lo verosímil” (220). 
cuerpo mercancía observa otras mercancías, en una realidad en la que el propio cuerpo encuentra su estatuto precisamente en el mercado. La escena se desespectaculariza en la repetición del cuadro sexual como una secuencia mal actuada, vacía y desganada.

Por otra parte, la presencia policial es desarticulada de su rol punitivo, vigilante y violento. En el espacio público, abierto, el baile y el cuerpo son erigidos como provocación, mientras "ellos" intentan cazarla, como si Eltit recuperara el tono acechante de Eloy de Droguett ${ }^{6}$ en relación con la noción de "novela del acoso" acuñada por José Promis ${ }^{7}$ (1993): "Quiero bailar ritualmente en las tardes crepusculares. Bailar para la policía arriba de la copa de agua tomando mi pelo mientras muevo los músculos, huesos y grasa en lo más alto de la copa iluminada por una luna tóxica. Bailar mientras ellos intentan cazarme con sus balines [...]" (Eltit 42). Una suerte de performance paródica hacia la autoridad, que busca provocarla, que retoma el gesto ochentero de la performance que Rubí Carreño lee como el "formato artístico que constituyó un soporte" creativo y de inserción en el campo cultural por parte de escritores como Eltit, Zurita, Lemebel (133) ${ }^{8}$.

En otro momento, los policías son presentados "como producciones animadas" (68), una puesta en escena imaginada, incluso ridiculizada, cuestionando su lugar político. Olga Grau entiende, por ejemplo, la performance del encapuchado, como una "geometría de los cuerpos que interactúan”, "una estética política” (202); por su parte, Román Domínguez la lee como arte irruptivo y "desafiante que escapa o trata -de escapar- a cualquier esfuerzo definitorio", que busca incomodar al receptor (7-9), en este caso, la autoridad. En el texto, Eltit resignifica la performance policial imaginada o animada, desarmando el rol de dominación, que es incomodada en su manera de actuar, incluso cuando esta construye su puesta propia en escena: "Un azote, uno

\footnotetext{
En Eloy podemos rastrear ese "ellos", como la tensión entre el sujeto criminal enfermo y la autoridad policial: "Están esperando que me muera lentamente, para ellos estoy gravemente enfermo, atacado de un mal incurable que se llama la vida, la necesidad de vida, desahuciado por sus balas, murmuraba desaprensivo, sonriendo sin alegría ni tristeza, solo vegetativamente" (Droguett 25-6).

Para Promis, el programa de la "novela del acoso" exhibe dos tendencias antagónicas, una, a partir de una "perspectiva social de base materialista dialéctica para interpretar los fenómenos de la realidad histórica" y otra sostenida por escritores "fieles al surrealismo o por novelistas mujeres, que dedican sus relatos al análisis de la realidad interior de la conciencia desde marcos de referencia subjetivos, oníricos, fantásticos, míticos o maravillosos" (113). De algún modo, Eltit articularía ambas tendencias, en su diálogo con las obras de Droguett y Bombal.

8 Carreño continúa, al sostener que, si en los ochenta la performance articula un gesto político, en los 2000 es el reality show “el que actúa [...] como alegoría del proceso de creación” (133).
} 
solo, realizado en el sector más neutro de la comisaría, un escenario que armó un oficial para entretener a los pacos de turno que estaban abatidos por el monto irrisorio que arrojaba la última gentrificación" (71). El triste espectáculo objeta la debilidad de la autoridad. Tiene sentido, entonces, la articulación que presenta Judith Butler, al sostener que la performatividad no es el acto "mediante el cual un sujeto da vida a lo que nombra", por el contrario, es "ese poder reiterativo del discurso para producir los fenómenos que regula e impone” (19). La novela cuestiona ese poder otorgándole el lugar dado del reparto en la escena pública ${ }^{9}$. Por cierto, el concepto de performance, "como práctica corporalizada y episteme" encuentra eco en la lectura de Diana Taylor (2017), para quien el concepto es "vital para redefinir los Estudios Latinoamericanos, al descentrar el papel histórico de la escritura introducido por la conquista" (52). La performance, en su paso por la novela, descentra la letra, gesto coherente en la lectura de Eltit.

\subsection{Imágenes y dispositivos}

El cuerpo se erige en el vínculo con ciertos dispositivos que canalizan imágenes. "Las computadoras del cíber", dice la narradora, "están lentas porque se están cayendo aceleradamente las conexiones" (124), lo que remite a cierta inestabilidad, tanto de la realidad virtual, como de la realidad propia. Si en Mano de obra "new forms of power and new technologies of exploitation are allegorized through narrative emplotment" (Dove 18), en Fuerzas especiales las tecnologías comunicativas y virtuales, los celulares y las fotografías digitales, siguen un camino similar, son algo turbio e inútil para sujetos "condenados a desaparecer" ${ }^{10}$, en rigor: "no logran revertir la condición social o existencial de sus consumidores. Internet, el epítome de la globalización, la más alta cumbre de la interactividad comunicacional, anula cada una de sus caracterizaciones positivas y se convierte en una escenografía, una interfaz cosificada" (Espinosa 229). Así, la inestabilidad del sistema específico posibilita la falla general

\footnotetext{
$9 \quad$ El poder siempre encuentra un polo opuesto. Eltit, sostiene Espinosa, propone dos polos: “uno, el del poder y sus esbirros, las fuerzas especiales; el otro, los pobladores, que parecieran haber abandonado cualquier forma de confrontación, cualquier deseo, sometidos al miedo, la violencia, al horror de la desaparición y la muerte" (227).

10 El grupo del portal que "comercializa guaguas", con "sus técnicas de camuflaje, bien intensos ellos, agudos, audaces, aparecen y desaparecen de las redes para desorientar a los tiras del mundo que están con sus caras pegadas a las pantallas. Policías ociosos, enfermos de imágenes prohibidas, recalentados por la censura" (Eltit 25-6).
} 
como crítica a ese referente. De hecho, es la posibilidad que tiene la narradora de gestionar: "Quisiera apagar el monitor y esperar mi muerte en el cubículo, sentada como un objeto en la silla de plástico para salir de manera apacible de la vida" (Eltit 144). Apagar el dispositivo es revocar su cualidad intrínseca.

La sujeción material con ciertos dispositivos permite pensar en Giorgio Agamben -en la línea cimentada por Foucault-, quien sostiene que en el vínculo entre "seres vivientes (o las sustancias)" (17) y “dispositivos" (18), aparece el "sujeto", quien constituiría el resultado de tales relaciones. De este modo, el dispositivo agambeneano sería cualquier objeto que "tenga la capacidad de capturar, orientar, determinar, interceptar, modelar, controlar y asegurar los gestos, las conductas, las opiniones y los discursos de los seres vivientes" (19). En ese sentido, no se acota solo en las instituciones recurrentes (prisiones, manicomios, panóptico, escuelas, confesión, fábricas, disciplinas, medidas jurídicas), con conexiones explícitas con el poder, "sino también la pluma, la escritura, la literatura, la filosofía, el cigarrillo, la navegación, las computadoras, los teléfonos celulares y -por qué no- el lenguaje mismo" (19). Asimismo, en la novela, apagar la pantalla implica acabar con el relato y, por consiguiente, con el lenguaje asediado por rifles, misiles, cohetes y metralletas. Una puesta en escena desbordada por el dispositivo armamentista.

En la novela el lenguaje está desbordado por pistolas, gorras, rifles, misiles, cohetes, proyectiles nucleares, bombas de neutrones, porras de plomo, dardos, espadas, cuchillos tácticos, carabinas semiautomáticas, metralletas, submarinos antinucleares, gases defoliantes (144), gases invalidantes (145), cañones de artillería mortero (158): "Había tres mil dispositivos de largo alcance LRAD” (161). Se trata de una puesta en escena desbordada por el dispositivo armamentista. También se enfatiza la mirada, la vigilancia: "Había quince mil visores engomados" (21), que dan cuenta de redes, poder y control. El cuestionamiento del rol de la autoridad podría ser leído desde la hiperbolización del lenguaje, puesto que el sujeto-policía desaparece. Al exacerbarse la cantidad de metralletas y cascos, se remarca la presencia del dispositivo en escena y no del sujeto que surge en la mediación de este mismo, como sugiere Agamben.

Otros dispositivos se erigen desde el uso de programas computacionales: "Ellos, los tiras y los pacos, tienen unos programas computacionales ligeramente distintos para investigar nuestros 
antecedentes" (65). A la vez, la protagonista venera la "neutralidad de la computadora" (13) que le protege "hasta los crujidos de mí misma" (14) o que le permite evadirse: "Tengo que olvidarme de mí misma para entregarme en cuerpo y alma a la transparencia que irradia la pantalla" (39). Escapatoria que busca, desde la técnica, cambiar el foco, es decir, "[u]n elemento exacto: una imagen, un recuerdo, un olor que fuera capaz de ingresar nuevas sensaciones que neutralizaran el malestar" (101). Sin embargo, mariposa y técnica, terminan siendo un tremendo fracaso, aunque la protagonista de Fuerzas especiales insista y busque alternativas que aplaquen el dolor:

Tengo que buscar otra imagen, lo sé, voy a hacer un recorrido muy exacto por los sitios hasta anular el dolor que me provocan las clavadas del lulo del hombre sentado en la silla de mi estrecho cubículo. Tengo que encontrar una imagen fija, lenta, opaca. Una imagen parecida al instante en que me despierto, cuando abro los ojos en medio de una ausencia que carece de límites y solo soy un espacio informe, un mundo entero que radica en mí. Si pudiera reproducir esa sensación y conseguir una imagen correcta sé que cada una de las medias horas dejarían de significar y no sería necesario untarme la crema que compré en la feria y meterme mis propios dedos para curarme las heridas que causa el lulo y así conseguir dormir de un envión en la noche. (104)

En consonancia con la hipótesis de este texto, se erige la idea de que la letra busca la imagen, otra imagen, articulando un regreso a la idea del cuerpo mercancía, sometido y herido, donde el cuerpo masculino y su significante pene es ridiculizado, referido o cosificado como mera masa muscular: lulo, que en Chile refiere a un elemento escatológico o a una masa moldeada con la mano. Una imagen que lidia con la ensoñación, que intenta equilibrar con la búsqueda material de la imagen. Imagen soñada e imagen referida, no es la imagen fotográfica que, según Perkowska (2013), constituye la "naturaleza referencial (mecánica indicial) [que] garantiza la autenticidad, confiriendo una autoridad particular a la imagen fotográfica" (44). En cierta forma, la apuesta de Eltit se inserta en lo que diversas teorías proponen ver en la fotografía: "una forma de signo con su propio código, su retórica y su manera de 'construir' la realidad, por lo cual el énfasis de la reflexión cae en los procesos y las prácticas que generan significados” (Perkowska 
44). La presencia del celular en la novela opera como un dispositivo de conservación del archivo de los tiras y, luego, del archivo del padre de la protagonista: "Quería subir esa imagen a las redes y mostrar su figura enjuta pero consistente. Deseaba enterrar su salida en el cementerio visual de las redes. Mi intención era retener a mi padre, capturarlo en mi celular, pero a la vez no podía desatender la escena entre mi madre y mi hermana" (55).

Los vínculos entre sujeto y dispositivo -y sujeto e imagen- configuran, en ocasiones, un grado de dominio y no de sometimiento, apreciándose cierto dinamismo: un sujeto activo que busca apagar la pantalla, obtener una imagen precisa u obtener un buen enmarque. Una escena de la derrota, en el sentido avelariano de la "alegoría de la derrota" y la estela de la narrativa de la postdictadura del Cono Sur que haría eco en la novela de Eltit, en la que quedan pocas opciones de resistencia, aunque, en pequeños gestos, ilumina un devenir que anuncia la posibilidad de un relato.

\subsection{El videojuego como forma de relato}

El último eje de análisis surge en la articulación de una narrativa audiovisual con la creación de un videojuego. En los años treinta, Walter Benjamin reflexiona en torno al silencio que acompaña a los soldados al regresar de la guerra. Se pregunta: “¿No se advirtió que la gente volvía enmudecida del campo de batalla?” (60), dando cuenta de que la experiencia no es comunicable (6o). La mudez o la dificultad literaria para narrar es comentada por Damián Tabarovsky (2015), quien vuelve sobre la ya conocida reflexión de Lyotard en torno a que lo único que se sabe hacer es contar que la historia es inenarrable. En este sentido, Tabarovsky sugiere que la novela, al narrar "debe responder a la pregunta sobre cómo narrar después de la pérdida de la inocencia de la narración” (79). En esa línea, Eltit, más que apostar por un trazo posmodernista, apunta a una perspectiva moderna, desde el momento en que asume el proyecto teórico de Rancière que postula que, frente a la derrota, aún quedan vestigios y posibilidades de narrar.

De algún modo, la mudez puede ser proyectada con la derrota y la imposibilidad de levantar un relato después de la crisis que surge en la novela de Eltit, en especial, la que experimentan los personajes en el capítulo final: "Juego del futuro". Nace la idea del videojuego como posibilidad de articular un relato desde la visualidad (que se construye desde la letra y la imagen), una narrativa audiovisual que enmarca la 
puesta en escena constante: "Y entonces aparecemos en la pantalla con el título que diseñamos: Pakos Kuliaos" (165). Retomando la lectura de César Barros (2013), es posible afirmar que surge nuevamente en esta obra la fuerza del lenguaje procaz; que se materializa el lenguaje como última posibilidad de levantar una lectura política que cuestione el "reparto de lo sensible" ranceriano.

Escritores como Joao Gilberto Noll, Mario Bellatin, César Aira y Washington Cucurto han publicado libros que imaginan artistas "consagrados a montar escenas en las cuales se exhiben" (Laddaga 166); escritores que construyen "dispositivos de exhibición de fragmentos de mundo" (167). Los personajes de Eltit, sin pertenecer al campo literario o artístico, ocupan un lugar con mucha carga simbólica en lo referido al impacto del videojuego como articulador de relatos, lo cual constituye un "pequeño gesto de rebeldía" (Espinosa 229). El dispositivo -vínculo entre espectáculo y juego- puede ser leído como pantalla lúdica, es decir, "una categoría cuya finalidad declarada es el entretenimiento, el juego, el espectáculo" (Lipovetsky y Serroy 285), vinculada específicamente con el cine debido a sus fuertes rasgos emocionales. Los videojuegos se clasifican en tres categorías - de reflexión, de acción y de simulación- y proponen "la inmersión en un mundo ficticio que cre[a] ilusión de realidad" $(286)^{11}$.

El rol del videojuego ${ }^{12}$, en tanto construcción de dispositivos y espectáculo de la realidad, enfatiza la idea de tránsito de la letra hacia la imagen en el proyecto escritural de Eltit. Cuestionamientos al lugar central o al reparto de lo sensible. El juego como dislocación, según Derrida, pone en cuestión las nociones de totalización y centro, por lo que funciona como un campo de sustituciones:

[...] ese movimiento del juego, permitido por la falta, por la ausencia de centro o de origen, es el movimiento de la suplementariedad. No se puede determinar el centro y agotar la totaliza-

\footnotetext{
11 Una definición simple de juego podría converger en la idea de ocio y luego derivar en dos variantes posibles: un juego libre y espontáneo, digamos imaginativo y creativo; otro, estructurado.

12 Idea de juego que permite relacionar la novela de Eltit, por ejemplo, con la de Nona Fernández, Space Invaders, en capítulos que hacen referencia al videojuego, como lo son "Primera vida" y "Segunda vida", además de los marcianitos del juego ochentero -del mismo nombre de la segunda novela aludida-, estética precisa para dar cuenta de la representación -que también erige, en tanto articulación generacional, Ruido de Álvaro Bisama-. Mientras Fernández sostiene que "Somos la gran pieza de un juego, pero todavía no sabemos cuál" (53), Eltit articula una idea de juego, de diseño y programación, la de un videojuego destructivo, estilo GTA, que interviene la novela. Otras obras que apuestan por una estética del videojuego-novela son: Oceana, de Maorí Pérez y Piezas secretas contra el mundo, de Carlos Labbé.
} 
ción puesto que el signo que reemplaza el centro, que lo suple, que ocupa su lugar en ausencia, ese signo se añade, viene por añadidura como suplemento". (397)

Todo suplemento es agregado, el diseño del juego, entonces, subvierte el diseño de los aparatos y tecnologías del poder, la escena está en manos de los sujetos que no toman parte del "reparto" ranceriano, crean el relato. De esta manera, Eltit ve en la ficción la posibilidad de jugar a derrotar la realidad, aunque sea solo una posibilidad y un juego que, de seguro, redundará en la derrota futura del sujeto.

\section{Conclusión}

“Dado que esta sociedad modela todo su entorno, ha erigido una técnica especial para trabajar la base concreta de todo este conjunto de tareas: su territorio mismo" (Debord 144). Eltit trabaja en línea con Debord y de pasada con Rancière. En ese gesto, en Fuerzas especiales, y en todo su trabajo literario, busca desarticular ese territorio debordiano desde el cuestionamiento del reparto de lo sensible ranceriano. En ese sentido, la vinculación letra-imagen, en Eltit, se traduce en un proyecto escritural que discute el estado pasivo de la letra y avanza hacia el régimen visual de esta, pero también sus espacios y territorios. Ese gesto, sin duda, es el proyecto político de la letra en sí, un proyecto que disloca y discute el "reparto de lo sensible" ranceriano.

Mitchell reflexiona respecto de la pregunta que habría que enunciar en torno a las relaciones de imagen-texto. Esta pregunta no es "¿Cuál es la diferencia (o similitud) entre las palabras y las imágenes?”, sino “¿Qué efectos tienen estas diferencias o (similitudes)?” (85); “¿por qué es importante la forma en que las palabras y las imágenes se yuxtaponen, se mezclan o se separan?" (85). En el vínculo de la letra con la imagen, la escena y el espectáculo -operaciones que ponen de manifiesto la función de la mirada- se cuestiona la significación inicial. Se la tensiona, en un sentido político, crítico, social y cultural. El cuerpo prostituido como mercancía frente a la pantalla; el videojuego desde su procacidad verbal y su imaginación/imagen violenta como relato; la espacialidad marginal como constructo; la performatividad imaginada de la policía.

El espectáculo, en el sentido debordiano crítico, se erige como “organización social presente de la parálisis de la historia y de la memoria, del abandono de la historia que se erige sobre la base del 
tiempo histórico, es la falsa conciencia del tiempo" (138). A contrapelo de esa lectura, en la novela de Eltit apagar la pantalla es acabar con el relato que propone la pantalla o espectáculo debordiano, por consiguiente, con el lenguaje armamentista desbordado. Luego, al articular uno propio desde una estrategia audiovisual de narración, el videojuego se erige en la posibilidad de utopía. En rigor, una forma ranceriana en que la literatura interviene en el recorte de los espacios. Eltit no descree de la narración, tampoco en una narración reinvidicadora, sino que con su proyecto político de intervención del recorte y del reparto no clausura la posibilidad de jugar, porque más allá de ganar o perder, se encuentra el hecho de generar y elaborar el juego, que constituye la posibilidad misma de intervenir, configurándose en el gesto político de una letra en tránsito constante hacia una imagen.

En Fuerzas especiales converge una lectura de lo político, entendido desde Rancière, Delleuze y Guattari, que articula un concepto en el que cada elemento, sujeto y dispositivo deriva en lo político, y en esa confluencia disloca lugares y territorios del reparto. Lo político tuerce la letra y la novela, cuestiona el poder y la autoridad, reordena el espacio y el territorio.

\section{Referencias bibliográficas}

Agamben, Giorgio. ¿Qué es un dispositivo? Buenos Aires, Adriana Hidalgo, 2014.

Avelar, Idelber. Alegorías de la derrota: La ficción postdictatorial y el trabajo del duelo. Santiago, Cuarto Propio, 2000.

Barrientos, Mónica. “Sujeto y bioespacio en la narrativa de Diamela Eltit”. Ciudades (in)ciertas. La ciudad y los imaginarios locales en las literaturas latinoamericanas, Comp. Adolfo de Nordenflych y Darcie Doll Ediciones Puerto de Escape, Valparaíso 2009. < http://letras.mysite.com/de070211.html>.

Barros, César. Escenas y obscenas del consumo. Arte, mercancía y visibilidad en el Cono Sur. Santiago, Cuarto Propio, 2013.

Benjamin, Walter. El narrador. Santiago, Metales Pesados, 2008.

Bongers, Wolfgang. "Literatura y cine fuera de sí: reflexiones sobre la intermedialidad en torno a Cinco metros de poemas de Carlos Oquendo de Amat". Profundidad de campo. Des/encuentros 
cine-literatura en Latinoamérica. Eds. Betina Keizman y Constanza Vergara. Santiago, Metales Pesados, 2016.

Butler, Judith. Cuerpos que importan. Sobre los limites materiales y discursivos del sexo. Buenos Aires, Paidós, 2015.

Carreño, Rubí. Memorias del nuevo siglo: jóvenes, trabajadores y artistas en la narrativa chilena reciente. Santiago, Cuarto Propio, 2009.

Debord, Guy. La sociedad del espectáculo. Valencia, Pre-Textos, 2012.

Deleuze, Gilles y Félix Guattari. “¿Qué es una literatura menor”. Kafka. Por una literatura menor. Ediciones Era, México, 1978.

Derrida, Jacques. "Las huellas de lo visible. Entrevistas". Artes de lo visible (1979-2004). Pontevedra, Ellago ediciones, 2013.

"La escritura, el signo y el juego en el discurso de las ciencias humanas". La escritura y la diferencia. Barcelona, Anthropos, 1989. 383-401.

Didi-Huberman, Georges. Supervivencia de las luciérnagas. Madrid, Abada, 2012.

Dove, Patrick. Literature and "Interregnum": Globalization, War, and the Crisis of Sovereignty in Latin America. Nueva York, University of New York Press, 2016.

Domínguez Ruvalcaba, Héctor. "La Yegua de Troya. Pedro lemebel, los medios y la performance". Ed. Fernando Blanco. Reinas de otro cielo. Modernidad y Autoritarismo en la obra de Pedro Lemebel. Santiago, Lom, 2004. pp. 117-149.

Eltit, Diamela. Lumpérica. Santiago, Seix Barral, 1998.

Fuerzas especiales. Santiago, Seix Barral, 2014.

Mano de obra. Santiago, Seix Barral, 2002.

Espinosa, Patricia. “Fuerzas especiales de Diamela Eltit: la microhistoria de la derrota y la resistencia del sujeto menor". Taller de Letras, no. 53, 2013, pp. 223-240.

Evans, Jessica y Stuart Hall. "Qué es la cultura visual”. Cuadernos de teoría y crítica. El giro visual de la teoría. Ed. Raúl Rodríguez Freire. Edición Independiente. Valparaíso, 2016.

Fernández, Nona. Space Invaders. Santiago, Alquimia, 2013.

Grau, Olga. "El encapuchamiento de la memoria”. Políticas y estéticas de la memoria. Ed. Nelly Richard. Santiago, Cuarto propio, 2000. 
Guerra, Lucía. “El conventillo: signo del desecho y signo híbrido en Los hombres oscuros, de Nicomedes Guzmán”. Anales de Literatura Chilena, no.1, Año 1, 2000, pp. 117-134.

Jameson, Fredric. Signaturas de lo visible. Buenos Aires, Prometeo Libros, 2012.

Laddaga, Reinaldo. Espectáculos de realidad: ensayo sobre la narrativa latinoamericana de las últimas dos décadas. Rosario, Beatriz Viterbo Editora, 2007.

Lértora, Juan Carlos. Una poética de literatura menor: la narrativa de Diamela Eltit. Santiago, Cuarto Propio, 1993.

Lipovetsky, Gilles y Jean Serroy. La pantalla global. Cultura mediática y cine en la era hipermoderna. Barcelona, Anagrama, 2009.

Matoso, Elina. El cuerpo, territorio de la imagen. Buenos Aires, Letra viva, 2007.

Mitchell, W.J.T. Teoría de la imagen. Madrid, Akal, 2009.

Montero, Loreto. “Diamela Eltit. Desde y fuera de la jaula. Fuerzas especiales”. Aisthesis, no. 56, 2014, pp. 217-220.

Olea, Raquel. "Contrapuntos narrativos. Lenguaje verbal e imagen visual en Lumpérica de Diamela Eltit”. Taller de Letras, no. 43, 2008, pp. 175-187.

Perkowska, Magdalena. “Intermezzo teórico: pliegues visuales”. Pliegues visuales: narrativa y fotografía en la novela latinoamericana contemporánea. Madrid, Vervuert, 2013.

Phillips, Rose. "Biopolitics and Sexuality in 2oth Century Latin American Dictatorships”. Tesis. Universidad de California, Irvine, <http:// escholarship.org/uc/item/3q5856ds>.

Promis, José. "La novela del acoso". La novela chilena del último siglo. Santiago, Editorial la Noria, 1993.

Rancière, Jacques. El espectador emancipado. Buenos Aires, Manantial, 2010.

El reparto de lo sensible estética y política. Buenos Aires, Prometeo Libros, 2014.

Política de la literatura. Buenos Aires, Libros del Zorzal, 2011.

Rojas, Sergio. Catástrofe y trascendencia en la narrativa de Diamela Eltit. Santiago, Sangría, 2013. 
Sibila, Paula. La intimidad como espectáculo. Buenos Aires, FCE, 2013.

Tabarovsky, Damián. Literatura de izquierda. Santiago, Libros La Calabaza del Diablo/Daskapital, 2015.

Taylor, Diana. El archivo y el repertorio. La memoria cultural performática en las Américas. Santiago, Ediciones Universidad Alberto Hurtado, 2017. 